\title{
INSTITUTIONAL PRESSURES, HUMAN \\ RESOURCE STRATEGIES, AND THE RISE OF NONUNION DISPUTE RESOLUTION PROCEDURES
}

\author{
ALEXANDER J.S. COLVIN*
}

\begin{abstract}
The author investigates factors influencing the adoption of dispute resolution procedures in the nonunion workplace. Various explanations are tested using data from a 1998 survey of dispute resolution procedures in the telecommunications industry. The results suggest that both institutional pressures and human resource strategies are factors driving the adoption of nonunion procedures. Among institutional factors, rising individual employment rights litigation and expanded court deferral to nonunion arbitration have led to increased adoption of mandatory arbitration procedures in the nonunion workplace. At the same time, an older institutional factor-union substitution by nonunion employers aimed at avoiding union organizing-continues to inspire the adoption of nonunion dispute resolution procedures, especially peer review. Finally, the results provide some support for a link between the use of high performance work systems and the adoption of nonunion dispute resolution procedures.
\end{abstract}

$\mathrm{C}$ onflict is an inherent part of the employment relationship. Given the combination of common and opposing interests and the ongoing nature of the relationship between employers and employees, it is inevitable that disputes will arise in the workplace. The procedures through which such disputes are resolved provide a basic indicator of the nature of governance of employment relations in the workplace. In

*Alexander J.S. Colvin is Assistant Professor, Department of Labor Studies and Industrial Relations, Pennsylvania State University. This paper is based on a multiyear research project on the Telecommunication Service Industry, funded by the Alfred P. Sloan Foundation. The author thanks Harry Katz, Rosemary Batt, Katherine Stone, Jeffrey Keefe, and Wendy Boswell for helpful comments. the American industrial relations system, this dispute resolution has taken place in unionized workplaces through highly developed, formal grievance procedures culminating in arbitration conducted by thirdparty neutral labor arbitrators. In contrast, for the vast majority of nonunion workplaces in the period following the Second World War, dispute resolution consisted of little more than the exercise of managerial discretion, and the few procedures that were established in the nonunion workplace most often soon fell into disuse (Slichter, Healy, and Livernash 1960).

Copies of data analyses and programs used to generate the results presented in this paper are available from the author at the Department of Labor Studies and Industrial Relations, Pennsylvania State University, University Park, PA 16802-2800.

Industrial and Labor Relations Review, Vol. 56, No. 3 (April 2003). (C) by Cornell University.

0019-7939/00/5603\$01.00 
However, evidence is growing of an expansion in recent decades of both the numbers and complexity of dispute resolution procedures in nonunion workplaces (Westin and Felieu 1988; McCabe 1988; Ewing 1989; Feuille and Delaney 1992; Feuille and Chachere 1995). This development assumes particular importance given that we are in a period of declining union representation coverage and the growth of new models of the employment relationship dominated by managerial human resource strategies and individualized employment rights. A key challenge for industrial relations research is to understand the nature of these new types of dispute resolution procedures and to explain why they are adopted in the nonunion workplace.

Developments in the area of dispute resolution procedures are relevant to the broader issue of what shape the governance of the workplace will take in a period of declining unionization following what has been described as the transformation of American industrial relations (Kochan, Katz, and McKersie 1994). Pessimists might predict an expansion of management authoritarianism in the workplace, with an absence of voice for the vast majority of workers. More optimistic observers might predict that management, awakening to the growing importance of workers as the unique human capital of the firm, will adopt human resource strategies under which nonunion employees are treated as valued organizational members whose concerns need to be taken into account in decisionmaking. Although opposite in polarity, these two views both suggest an employment future dominated by managerial human resource decision-making rather than institutional forces. In contrast to these perspectives, the arguments and evidence I present here suggest that although new work organization and human resource strategies are reshaping the workplace, institutional forces continue to exert a powerful influence on the governance of employment relations, even for nonunion employees.

What might account for adoption of dispute resolution procedures in the nonunion workplace? In this study, I test for the agency of three possible factors. The first is the adoption of dispute resolution procedures in conjunction with practices associated with high performance work systems. It could be that nonunion dispute resolution procedures are adopted in furtherance of strategies for management of the work force that emphasize fair treatment of employees as a way to increase organizational commitment, reduce turnover, and enhance performance. A second factor that may explain the adoption of nonunion dispute resolution procedures is institutional pressures from litigation. Litigation based on individual employment rights is one major way nonunion employees can exert direct pressure on employers. In the 1990s, however, a new tool for avoiding litigation emerged as the U.S. Supreme Court held that statutory employment law disputes, such as claims of discrimination based on Title VII of the Civil Rights Act of 1964, could be subject to an arbitration agreement between the employer and a nonunion employee. This decision created a strong incentive for employers to adopt nonunion arbitration procedures that serve as effective bulwarks against employment litigation.

A third factor that will be examined, union substitution, has long been deemed an institutional inducement for the adoption of nonunion dispute resolution procedures (for example, Berenbeim 1980). Some have argued that the importance of this factor has diminished with declining unionization (Feuille and Delaney 1992). In a new development, however, some nonunion employers in recent years have adopted peer review procedures in which employees who are peers of the complainant decide whether the employee's complaint should be upheld. These peer review procedures constitute a new type of dispute resolution process using non-managerial decision-makers that could serve a union substitution function.

In general, the expansion of nonunion dispute resolution procedures, particularly those including due process protections such as the use of non-managerial decision- 
makers, might be seen as a positive development indicating greater justice and industrial citizenship for employees in the nonunion workplace. Yet the institutional dynamics suggested by the second and third factors described above indicate that these dispute resolution procedures occupy a more ambiguous place in nonunion industrial relations. Although third-party arbitrators or peer review panels may, from employees' perspective, represent an improvement in due process over the use of managers as the final decision-makers in a procedure, the impetus for the adoption of these procedures is the protection of the firm against institutional pressures from outside the organization. Like walls around a citadel, these procedures help prevent intrusion by outside actors-notably, in this case, unions and the courts.

Below, I first analyze in more detail the factors that may be influencing the adoption of nonunion dispute resolution procedures. The impact of these factors is then examined using survey data on organization-level variation in the adoption of procedures among establishments in the telecommunications industry. Although the primary empirical focus here will be on these survey data, the arguments and analysis presented were in part developed through a set of preliminary case studies of the adoption of nonunion dispute resolution procedures. The case studies (described in detail in Colvin 1999) were based on interviews conducted in 1997-98 at four companies. Individual interviews averaged 1 to $1-1 / 2$ hours in length, and interview subjects included corporate, divisional, and plant-level human resource managers, inhouse counsels specializing in employment and labor law, and in-house general counsels.

\section{Factors Influencing the Adoption of Nonunion Dispute Resolution Procedures}

\section{High Performance Work Systems}

I first investigate whether nonunion dispute resolution procedures are adopted as part of more general work organization and human resource management strategies put in place by the organization. If there is such a link, one implication is that the adoption of dispute resolution procedures enhancing protection of employee rights will be more likely where the organization has adopted other practices and procedures that enhance the status of employees within the organization. In particular, a link may exist between the adoption of dispute resolution procedures and high performance work systems, which have been advocated as both improving organizational performance and enhancing the quality of jobs for employees. High performance work systems (HPWSs) encompass work organization and human resource strategies aimed at promoting high levels of employee commitment and involvement in the workplace in order to increase quality, productivity, and responsiveness to customers (Ichniowski et al. 1996). Although most descriptions of HPWSs focus on such practices as use of self-managed work teams, high levels of ongoing training, and employment stabilization (MacDuffie 1995; Delery and Doty 1996; Appelbaum et al. 2000), a few researchers have also included formal dispute resolution procedures among practices and procedures seen as indicating the presence of high involvement work systems (Arthur 1992; Huselid 1995).

Exit-voice theory provides one theoretical rationale for anticipating such a link between high performance work systems and the adoption of dispute resolution procedures. As applied to the employment context, exit-voice theory suggests that when confronted with problems in the workplace, employees have at least two possible courses of action available to them: exit, that is, quitting to avoid the problem, or voice, that is, complaining about the problem (Freeman and Medoff 1984). To the degree that use of voice is facilitated through structural mechanisms in the workplace, such as formal dispute resolution procedures, the relative use of the alternative exit option and resulting turnover costs will be reduced. The organization's turnover 
costs are likely to be increased under high performance work systems due to the high levels of firm-specific skills and commitment needed in the work force (Shaw et al. 1998), and therefore the motivation to adopt dispute resolution procedures should be stronger where organizations have adopted HPWSs.

An alternative rationale for expecting a link between the adoption of dispute resolution procedures and HPWSs comes from organizational justice theory. Organizational justice research indicates that perceptions of both procedural and distributive justice enhance employee job satisfaction and promote organizational commitment (Sheppard, Lewicki, and Minton 1992; Folger and Cropanzano 1998). Supporting this insight, experimental study results indicate that access to a grievance system enhances employees' willingness to continue working for the organization (OlsonBuchanan 1996). Since inducing high levels of employee commitment is a key HPWS goal (Osterman 1995), adoption of nonunion dispute resolution procedures that help promote greater organizational justice is likely to be associated with adoption of other elements of high performance work systems, such as self-directed work teams, high levels of ongoing training, and employment stabilization policies.

These theoretical explanations fit with some of the explanations offered by managers, in the preliminary case studies, for why their organizations adopted nonunion dispute resolution procedures. For example, the Vice-President of Human Resources at a division of one case study company with particularly strong HPWS policies offered as justifications for a new nonunion dispute resolution procedure that it was in keeping with "the spirit of a modern company" and responded to the demands of a work force "who want a say in the business" (Colvin 1999:127). Although these concerns might not be important for other firms, the point made by this manager when he urged his colleagues to adopt the new dispute resolution procedure was that the organization's use of participation programs, such as self-managed work teams, to enhance productivity and quality had increased expectations among employees that they should have voice in other areas of employment as well.

Hypothesis 1: The likelihood that nonunion dispute resolution procedures are adopted will be positively associated with the adoption of high performance work systems.

\section{Litigation Threats and the Adoption of Nonunion Arbitration}

The rise of nonunion arbitration procedures in the 1990s provides a strong example of how changes in the legal environment can inspire a major shift in organizational practices. Prior to the 1990 s, internal dispute resolution procedures were only a limited tool with which organizations could avoid litigation. Although such procedures might reduce litigation through preventive resolution of conflicts, the mere existence of some form of dispute resolution procedure within the organization could not bar litigation by employees or provide an effective defense in the event that litigation did occur (Edelman, Uggen, and Erlanger 1999). This picture changed dramatically in the 1990s as the courts suddenly began to recognize nonunion arbitration as a type of dispute resolution procedure that would effectively serve as a mechanism by which organizations could bar employee access to the courts.

In its 1991 decision in Gilmerv. Interstate/ Johnson Lane, 500 U.S. 20 (1991), the United States Supreme Court held for the first time that a dispute based on a statutory employment right was subject to arbitration. Following Gilmer, the courts have held that the full range of employment laws are subject to arbitration clauses included in the employment contracts of nonunion employees, including the major anti-discrimination laws such as Title VII of the Civil Rights Act, the Age Discrimination in Employment Act, and the Americans with Disabilities Act (Stone 1996; Stone 1999; Zack 1999). More recently, the Supreme Court reaffirmed this shift in the law with its decision in Circuit City v. Adams, 121 S. Ct. 1302 (2001), which rejected attempts to 
limit the scope of Gilmer based on alternative readings of the employment clause exclusion contained in the Federal Arbitration Act.

The practical significance of the enforcement of these "mandatory arbitration" agreements is that they require diversion of all employment litigation, including Title VII and other discrimination cases, into an employer-designed arbitration procedure from which there is no right of appeal and only very limited possibility of court review (Stone 1996). There has been much debate over these mandatory arbitration procedures and various proposals to enhance their due process features (Dunlop and Zak 1997). However, even among mandatory arbitration procedures that feature relatively strong due process protections, cases are still heard by arbitrators who are generally perceived as highly unlikely ever to recommend an extremely large award for a plaintiff-an occasional practice for which juries have gained notoriety. Mandatory arbitration as a device for effectively avoiding jury trials may be powerfully attractive to employers who are haunted by visions of runaway juries recommending colossal awards.

The adoption and enforcement of mandatory arbitration procedures has been extremely controversial (Stone 1999; Zack 1999), due in part to the contradictory nature of these procedures. Nonunion arbitration initially appears to have some attractive features, such as a third-party neutral decision-maker, decisions based on legal rules rather than company policies, and faster resolution of cases than is usually possible in the court system. Yet in the case of mandatory arbitration, these and other potential benefits of arbitration are obtained at the cost of eliminating the possibility of court review. Notwithstanding the importation of presumably neutral arbitrators, under mandatory arbitration the rights of employees as citizens in the organization are enforceable only through an employerdesigned private system of justice established within the bounds of the organization, which thus becomes a citadel isolated from outside scrutiny by the courts.
From an organization's standpoint, mandatory arbitration provides a powerful response to pressures from employment litigation, but it also poses new costs of uncertain magnitude. The organization must pay for administration of the new procedures, including arbitrator fees, which may be substantial. Although critics have tended to focus on the barriers to employee access to mandatory arbitration, in the preliminary case studies managers often expressed the opposing concern that adopting mandatory arbitration would lead to a substantial increase in the number of employee complaints being filed, imposing additional costs on the company (Colvin 1999). Adoption of mandatory arbitration is probably more likely when the organization perceives substantial threats from litigation that outweigh these potential costs. Respondents for two of the companies included in the case studies, in fact, said that their firms adopted mandatory arbitration as a direct response to large increases in employment litigation following downsizing in the early 1990s (Colvin 1999).

The extent of the litigation threat will vary with both the extent of substantive legal protections and the degree to which the laws in question are likely to be applicable to the organization's work force. State courts vary widely in the extent to which they have recognized exceptions to the general rule of employment-at-will, leading to cross-state variation in the threat perceived from litigation (Dertouzos, Holland, and Ebener 1988; Dertouzos and Karoly 1991; Edelman, Abraham, and Erlanger 1992). Some managers in interviews, giving voice to this fear, cited California as a state in which employment litigation posed a particularly strong threat, with plaintiff employment attorneys in the 1990s "starting to advertise their services on billboards at the side of highways" (Colvin 1999:135).

Whereas wrongful discharge laws vary from state to state, the prohibitions against discrimination in employment under Title VII, the ADEA, and other federal legislation apply to employees in all states equally. However, the frequency of employment discrimination litigation is apt to vary from 
company to company as a function of work force composition: companies with high proportions of employees in minority classes that have most frequently been the plaintiffs in litigation under the statutes may be especially vulnerable. For example, female employees are more likely than male employees to be plaintiffs in discrimination litigation, and therefore the probability of discrimination litigation should increase with the proportion of the work force that is female (Epp 1990; Edelman, Uggen, and Erlanger 1999).

Hypothesis 2: The likelihood that nonunion arbitration procedures are adopted will be positively associated with the strength of the threat of litigation against the organization.

\section{Unionization Threats and the Adoption of Peer Review}

The threat of unionization can strongly influence the organizational practices of nonunion employers. Both historical research (Edwards 1979) and contemporary research (Kochan, Katz, and McKersie 1994; Taras 1997) have provided evidence of nonunion employers adopting practices copied from unionized workplaces in order to fend off unionization. If the nonunion employer can offer a substitute for the benefits offered by the union, it may be able to reduce the chance of a successful union organizing drive. However, whereas nonunion employers can counter union promises of improved wages directly by matching the wages of unionized competitors (Taras 1997), it is much harder for them to match the workplace justice protections provided to employees by union grievance-arbitration procedures. First, no equivalent of a union's representation of employees is found under nonunion procedures. Second, nonunion procedures typically lack an independent final decision-maker, in contrast to the neutral labor arbitrators used as the final step in union grievancearbitration procedures. This is not to say that union procedures are without flaws, but rather that the relative weakness of typical nonunion procedures can become an important issue in organizing drives, where questions of workplace justice are often of critical importance (Bronfenbrenner 1997).

Although some have argued that union substitution has diminished in importance as a factor in the adoption of nonunion procedures (Feuille and Delaney 1992), one of the unexpected findings of the preliminary case studies was that organizations were introducing new types of dispute resolution procedures with union substitution as a direct motivation. Most notably, two of the organizations examined had adopted peer review procedures as a "counter-defensive" move (in the words of one manager) to avoid becoming a target of union organizing drives (Colvin 1999:127). Under peer review procedures, review panels or boards are established to hear and decide employee grievances (Ewing 1989; Lewin 1997; Colvin 1999). The key feature of these panels - that the majority of their members are peers of the grievant-creates two important advantages for their use as union substitution mechanisms. First, because a majority of the final decisionmakers in the procedure are no longer members of management, the panels promise greater neutrality in decision-making. Second, because employees are involved in the procedure, there is some substitution for the representational function of the union in the workplace-albeit only partial substitution, given that the panel members are not actually presenting the grievance on behalf of the employee.

This form of nonunion employee representation also has significant advantages for management as a union substitution device, because peer review panels can be designed to avoid the danger of violation of section 8(a) (2) of the National Labor Relations Act, which renders illegal some other forms of nonunion employee representation established and dominated by employers. In its decision in Keeler Brass, 317 N.L.R.B. 1110 (1995), the National Labor Relations Board held that peer review type panels did not violate section 8(a) (2) so long as they simply issued final decisions on employee grievances and did not attempt to "deal with" management by negotiating 
how grievances were to be resolved. The ability of peer review panels to function legally within the confines of the general legislative prohibition on nonunion employee representation plans creates a strong institutional incentive for employers to adopt this form of employee involvement in dispute resolution to help forestall threats of unionization.

As with the use of mandatory arbitration in response to the threat of litigation, peer review procedures adopted to avoid unionization exhibit a duality in their role. On the one hand, they serve to enhance fairness in dispute resolution by replacing the managerial decision-maker of typical nonunion grievance procedures with a panel on which fellow employees are represented, providing a perspective on the dispute that is closer to that of the employee complainant (Klaas and Feldman 1993). On the other hand, management's adoption of these procedures reduces the chances of representation by a union that might more effectively protect employees. Thus, the rights of employees as citizens within the organization achieve legitimacy and are accommodated, but in the context of protection of the organizational citadel from the external institutional pressures exerted by unions.

Similar to pressures from litigation, the threat of unionization will vary substantially across organizations. Unionization varies widely across regions and industries (Katz and Kochan 2000). Beyond variation in levels of unionization, states differ substantially in the extent of legal and political support for unions. Most notably, "rightto-work" states, concentrated in the South, have created environments markedly hostile to union organizing efforts (Katz and Kochan 2000). The seriousness of the unionization threat, as mediated by such factors, probably affects the degree to which organizations feel pressure to adopt practices and procedures directed at warding off unionization.

Hypothesis 3: The likelihood that peer review procedures are adopted will be positively associated with the strength of the threat of unionization against the organization.

\section{Data}

The survey data analyzed here were collected as part of a broader study of work organization and employment practices in the telecommunications industry. Following an initial telephone survey of establishments in the industry that collected data on work organization and employment practices, respondents from a random subset of establishments were asked to answer a more detailed set of questions on dispute resolution practices. The sampling frame was constructed by drawing a stratified random sample from a population provided by the Dun and Bradstreet listing of establishments, which includes SIC code industry classifications. Establishments were stratified by size, with almost all establishments with more than 100 employees included in the sample. Smaller establishments were stratified by SIC code so that the total sample reflects the relative proportion of establishments in the three major parts of the industry: wireline (SIC 4813); cellular (SIC 4812); and cable TV (SIC 4841). Because internet providers are an important new part of the industry that is not systematically captured by SIC code, additional ISPs were identified through the Directory of National Dialup Providers and Area Codes of Operation. Finally, the sample was stratified by the states in which the establishments were located, with all states represented in the sample.

Use of the establishment as the unit of analysis, which follows prior research on variation in employment practices (Osterman 1994, 2000), has the advantage that establishment-level respondents' answers to questions about practices are more likely to be accurate than answers by respondents at the divisional or corporate levels of organizations, who are likely to be less directly involved in practices in the workplace. In addition, the preliminary case study research found significant variations in practices among establishments within the same companies.

A university-based survey team administered the survey by telephone in the fall of 1998. The respondents to the survey ques- 
tions were the general managers of the establishments. The initial telephone interviews yielded a $54 \%$ response rate. Information from the Dun and Bradstreet establishment database allowed checks on the representativeness of the respondents on a number of dimensions. There were no statistically significant differences between respondents and non-respondents on whether or not the establishment was a branch of a larger organization, whether it was publicly or privately held, or whether it was owned by a former Bell system company. Internet service providers were somewhat less likely to respond than were general managers from the other sectors, perhaps because they are less likely to selfidentify with the telecommunications industry. Smaller establishments were somewhat more likely to respond than were larger establishments.

A random subsample of establishments was surveyed about dispute resolution procedures and practices a few weeks following the initial survey. The response rate to the dispute resolution survey was $75 \%$, yielding 302 responses. This survey used the same individual informants as the initial work organization and human resource practice survey, and it too was conducted by telephone. In order to focus the investigation on variation in nonunion dispute resolution procedures, data analysis was restricted to establishments having no unionized employees, of which there were 213. Missing data reduced the number of observations usable in the data analysis to 165 .

This two-stage approach to developing the sampling frame has both advantages and disadvantages. The most obvious disadvantage is that asking respondents to reply to two surveys increases the effective non-response rate. Combining a 54\% response rate to the initial work organization and human resource practice survey with the $75 \%$ response rate to the dispute resolution survey yields an effective response rate to the latter survey of $40.5 \%$. The main advantage of this two-stage method is that it allows data from the first survey, in which respondents were not being asked about dispute resolution, to be used to check the representativeness of those respondents who were willing to answer the dispute resolution survey. This provides a partial check on the danger of selection bias. Comparison of respondents and non-respondents using t-tests revealed only two statistically significant differences on the independent variables found in both datasets: compared to non-respondents' establishments, respondents' establishments were located in areas with lower unemployment rates $(4.1 \%$ versus $4.8 \%, \mathrm{p}<.01)$ and had slightly lower average employee education levels $(13.6$ years versus 13.9 years, $p<.10$ ) Based on these comparisons, differences between respondents and non-respondents in this sample appear relatively minor.

\section{Dependent Variables}

As discussed earlier, dispute resolution procedures in the nonunion workplace feature a wide range of types of procedures. At a basic level, one can ask whether there is any formal procedure at all for the resolution of employee complaints in a nonunion workplace. Although this threshold question was asked in the survey, the primary focus in the analysis here will be on the adoption of procedures that feature nonmanagerial decision-makers, in particular nonunion arbitration procedures and peer review panels. Procedures that feature nonmanagerial decision-makers represent a more significant potential shift in the governance structure of employment relations than simple formalization of managerial review of employee complaints.

The presence of each type of procedure, nonunion arbitration and peer review, is represented by a single dummy variable that indicates whether or not the establishment has this type of procedure covering its nonunion employees. An additional question asked what proportion of nonunion employees was covered by the procedure in question, but in this sample all procedures that had been adopted covered all nonunion employees in the establishment. Whereas both nonunion arbitration and peer review are often part of general procedures covering all disputes in the work- 
place, some procedures are limited to discipline and discharge disputes. This is particularly true for nonunion arbitration, which may be introduced simply to cover discharge or other cases that have the potential to lead to litigation. At the basic level of whether or not these procedures were present in the establishment, both nonunion arbitration and peer review were coded as present if they were used either for discipline and discharge cases only or as part of a general dispute resolution procedure covering various types of workplace disputes.

\section{Independent Variables}

High performance work systems. A major methodological debate in research on high performance work systems concerns whether to construct scales representing the presence of such systems or to examine individual practices associated with the systems. Although a number of different scales representing bundles or clusters of high involvement practices have been constructed and used by researchers (for example, Arthur 1992; Huselid 1995; MacDuffie 1995; Ichniowski, Shaw, and Prennushi 1997), these scales have been subject to much debate, and no strong consensus has been reached over what elements to include in them (Delery 1998). As a result, I will follow here the alternative approach of using measures of individual human resource practices that are considered important indicators of high involvement work systems (Shaw et al. 1998).

Four variables capture aspects of high performance work systems, two of them representing practices associated with HPWSs, two representing non-HPWS approaches to management of the work force. The first variable, teams, measures the proportion of the core work force organized into self-directed teams. The second variable, training, measures the number of days of ongoing training provided to workers annually. The third variable, temporary workers, measures the proportion of temporary employees among the work force. Finally, the fourth variable, electronic monitoring, measures the proportion of time that workers are electronically monitored. Whereas higher scores on teams and training indicate the presence of high performance work systems, higher scores on temporary workers and electronic monitoring indicate the absence of such systems.

Litigation threats. Two variables provide indicators of the extent of potential threats from litigation. The coverage of state employment laws is captured by a single variable, implied contract, measuring whether or not the state in which the establishment is located had adopted the implied contract exception to employment-at-will by 1996 (BNA 1999). The reason for emphasizing the implied contract exception is that past research has regarded it as the most farreaching modification of the at-will rule, providing the broadest potential coverage of employment disputes (Edelman, Abraham, and Erlanger 1992), and has found it to be more strongly associated with employment outcomes than are other exceptions to the at-will doctrine (Miles 2000). The year 1996, which was two years prior to the survey, is used as a cut-off in order to partly account for a potential delay in the effect of implementation of a new legal rule on the behavior of organizations. Although state level measures are somewhat crude indicators of variation in litigation pressures, the sample does have reasonable cross-state representation, with 44 different states included in the final sample.

Second, the variable female measures the proportion of employees who are female, which also serves as a proxy for the potential threat of discrimination litigation (in contrast with the usual use of this variable as an indicator of work force marginalization and absence of formal employment policies). Discrimination laws are in part directed at helping remedy the position of historically marginalized groups. As a result, where such groups constitute larger portions of the work force, the challenge of employment discrimination laws to existing power relationships within the organization will be correspondingly greater.

Unionization threats. The extent of the 
unionization threat is measured by two variables. The strength of the union organizing threat in the state of location of the establishment is measured by the variable right-to-work, which indicates whether the state has passed a right-to-work law. Although right-to-work laws only directly serve to ban dues shops, in which unions can require non-members whom they represent in unionized establishments to pay dues, the status of a state as a "right-to-work state" serves as an indicator that the state has a strongly anti-union orientation. This is reflected in the trumpeting of the "rightto-work" status of these states in advertising that seeks to persuade businesses to relocate their operations to these states.

The degree to which management is directly motivated to introduce dispute resolution procedures in response to the threat of unionization is captured by a single measure. The variable union substitution is based on a single survey question asking respondents to indicate on a seven point Likerttype scale the degree to which management tries to provide a substitute for union grievance-arbitration procedures in handling employee complaints. Although this is a rather simplistic measure, it is included in the analysis because it fairly directly distinguishes between procedures oriented toward union avoidance and procedures motivated by other considerations, such as litigation threats or employee turnover costs.

\section{Other Establishment and Work Force Characteristics}

Two factors that may have a substantial positive effect on the likelihood of the adoption of procedures are employee tenure and compensation levels. These two factors do not, however, clearly differentiate between the various theoretical explanations discussed above. One would predict that higher levels of work force human capital, associated with higher wage and tenure levels, would increase the incentive to adopt dispute resolution procedures in order to reduce costly turnover. However, threats from litigation should also increase with the wage and tenure levels of employ- ees, which increase the potential damages from employment litigation. Given that these theoretical explanations yield similar predictions for the effect of higher employee compensation and tenure levels, these variables are not associated with any single explanatory factor. Employee pay is captured by a single variable, average pay, measuring the natural log of average annual employee pay in the establishment. Two variables capture the length of employee tenure: short tenure measures the proportion of employees with less than one year of tenure with the establishment, and long tenure measures the proportion of employees with more than ten years' tenure.

A series of other establishment and work force characteristics are also included in the analysis as control variables. The variable size measures the total number of employees (in hundreds) working in the establishment, which functionalists have argued is associated with greater formalization of organizational practices and procedures (for example, Blau and Schoenherr 1971). The variable exempt measures the percentage of employees in the establishment who are categorized as exempt from hour and wage laws. The variable education level measures the average years of education of employees in the establishment. The variable unemployment introduces a control for the local unemployment rate in 1998 in the area where the establishment is located. This last control variable is included because prior case study research has indicated that local unemployment rates often affect the exit-voice trade-off for employees when they are confronted with problems on the job. Unemployment rates in some cases could substantially affect the threat of employment litigation, with employees in areas where unemployment was relatively low being much less likely to sue their employer following dismissals and much more likely to find alternative employment quickly.

\section{Results}

Means, standard deviations, and correlations for the variables are reported in Table 1 . 
Table 1. Means, Standard Deviations, and Correlations of the Variables.

\begin{tabular}{|c|c|c|c|c|c|c|c|c|c|c|}
\hline & Mean & S.D. & 1 & 2 & 3 & 4 & 5 & 6 & 7 & \\
\hline 1. Nonunion Arbitration & 0.224 & 0.418 & 1 & & & & & & & \\
\hline 2. Peer Review & 0.200 & 0.401 & 0.24 & 1 & & & & & & \\
\hline 3. Size & 1.505 & 3.456 & -0.08 & 0.06 & 1 & & & & & \\
\hline 4. Exempt & 0.377 & 0.318 & 0.01 & -0.06 & 0.08 & 1 & & & & \\
\hline 5. Education & 13.594 & 1.588 & -0.01 & 0.00 & -0.01 & 0.34 & 1 & & & \\
\hline 6. Unemployment & 4.033 & 1.637 & 0.04 & 0.15 & 0.00 & -0.14 & -0.23 & 1 & & \\
\hline 7. Short Tenure & 0.258 & 0.266 & -0.12 & -0.20 & 0.06 & -0.09 & 0.04 & -0.03 & 1 & \\
\hline 8. Long Tenure & 0.288 & 0.337 & 0.16 & 0.10 & 0.00 & -0.06 & 0.01 & 0.01 & -0.14 & \\
\hline 9. Pay (Log) & 10.359 & 0.488 & 0.11 & 0.04 & 0.08 & 0.39 & 0.63 & -0.20 & -0.15 & \\
\hline 10. Teams & 0.187 & 0.334 & 0.10 & 0.17 & -0.08 & -0.07 & -0.03 & -0.15 & -0.12 & \\
\hline 11. Training & 2.058 & 1.595 & 0.21 & 0.10 & -0.05 & 0.00 & -0.03 & -0.01 & -0.10 & \\
\hline 12. Temps & 0.049 & 0.148 & -0.05 & -0.11 & -0.05 & -0.02 & 0.02 & 0.02 & 0.10 & \\
\hline 13. Electronic Monitoring & 0.304 & 0.404 & 0.01 & 0.12 & 0.20 & -0.05 & -0.21 & -0.05 & 0.16 & \\
\hline 14. Implied Contract & 0.709 & 0.456 & 0.12 & 0.02 & -0.03 & -0.09 & -0.10 & 0.14 & -0.04 & \\
\hline 15. Female & 0.440 & 0.368 & 0.07 & -0.05 & 0.11 & -0.02 & -0.14 & 0.07 & 0.09 & \\
\hline 16. Union Substitution & 3.770 & 2.232 & 0.12 & 0.18 & 0.20 & -0.04 & -0.20 & -0.07 & -0.11 & \\
\hline \multirow[t]{2}{*}{ 17. Right to Work } & 0.382 & 0.487 & -0.09 & -0.17 & -0.03 & -0.07 & -0.04 & 0.00 & 0.06 & \\
\hline & 8 & 9 & 10 & 11 & 12 & 13 & 14 & 15 & 17 & 18 \\
\hline 8. Long Tenure & 1 & & & & & & & & & \\
\hline 9. Pay (Log) & 0.01 & 1 & & & & & & & & \\
\hline 10. Teams & 0.03 & 0.01 & 1 & & & & & & & \\
\hline 11. Training & 0.01 & 0.05 & 0.07 & 1 & & & & & & \\
\hline 12. Temps & -0.02 & 0.01 & 0.03 & -0.08 & 1 & & & & & \\
\hline 13. Electronic Monitoring & 0.06 & -0.32 & -0.03 & 0.03 & -0.01 & 1 & & & & \\
\hline 14. Implied Contract & 0.01 & -0.10 & -0.06 & -0.03 & 0.00 & 0.09 & 1 & & & \\
\hline 15. Female & -0.09 & -0.40 & -0.13 & 0.00 & -0.14 & 0.19 & 0.05 & 1 & & \\
\hline 16. Union Substitution & 0.20 & -0.06 & 0.05 & 0.08 & -0.06 & 0.13 & 0.01 & 0.05 & 1 & \\
\hline 17. Right to Work & 0.06 & 0.01 & 0.16 & -0.12 & 0.04 & -0.09 & -0.21 & -0.06 & -0.03 & 1 \\
\hline
\end{tabular}

Any correlation with an absolute value of 0.16 or higher is significant at the .05 level.

Distribution of procedures. The means in Table 1 from one perspective overstate the overall percentage of establishments with nonunion dispute resolution procedures. Since the focus of this study is variation in the adoption of procedures covering nonunion employees, I have included only nonunionized establishments in the data analysis. Consequently, overall percentages of nonunion procedures among the full sample, including both union and nonunion establishments, are lower. Overall, in the full sample $16.3 \%$ of establishments have nonunion arbitration procedures covering core employees and $15.9 \%$ have peer review procedures.

Conversely, these percentages only provide a lower bound on the total incidence of procedures, since some establishments in which the core employees are unionized may also have dispute resolution procedures covering their remaining nonunion employees. Procedures covering these employees, typically managers in unionized establishments, are not included in the analysis, since the dynamics of adoption of procedures for this group may differ, particularly in regard to unionization threats that are not relevant for them. In addition, the data on work organization and human resource practices gathered relate to practices as applied to core employees, rather than to managerial employees.

Given that this survey is industry-specific, the incidence of procedures in the sample may not be representative of the economy as a whole. However, it is interesting to compare the incidence of nonunion arbitration procedures to previous estimates given the impetus provided to the adoption of arbitration by the Supreme Court's 1991 decision in Gilmer v. Interstate/Johnson Lane discussed above.

In a study based on a 1991 survey of alumni of a masters program in human 
resources and industrial relations, Feuille and Chachere (1995) found that only about $2 \%$ of organizations used arbitration in nonunion grievance procedures. This proportion is particularly low given that their sample likely included a relatively high proportion of companies with more professionalized and sophisticated management of human resources. In contrast, a 1995 study by the General Accounting Office (GAO 1995) found that $9.9 \%$ of organizations in a sample of federal contractors had adopted nonunion arbitration procedures. Although these results should not be over-generalized, the finding in this study of a $16.3 \%$ adoption rate for nonunion arbitration procedures covering core employees is consistent with anecdotal impressions of a rapid expansion of nonunion arbitration procedures during the 1990s in the wake of the Gilmer decision. Perhaps more surprising in this sample is the almost equally high $(15.9 \%)$ incidence of peer review panels, a type of procedure that has received much less academic research and public policy examination. As will be argued below, this incidence may reflect the strong association of adoption of peer review procedures with union substitution motivations and continued union strength in the telecommunications industry.

Regression estimates. Regression results are presented in Table 2, with the first model estimating the prediction equation for nonunion arbitration and the second model estimating the prediction equation for peer review procedures. Logit regressions were used for estimating the procedure type variables, nonunion arbitration and peer review, both of which are dichotomous $0-1$ variables, with 1 representing the presence of the procedure. Some establishments in the sample were part of the same companies, partially violating the assumption of independence of observations. To deal with this problem, a Huber (1967) correction for clustering of observations was used in the regressions. Groups of independent variables representing alternate explanations for the adoption of dispute resolution procedures were also en- tered hierarchically to allow for testing of their joint significance.

High performance work systems. Hypothesis 1 proposed that adoption of high performance work systems would be associated with the adoption of nonunion dispute resolution procedures. Addition of the group of four HPWS variables did not produce a statistically significant improvement in the first model. Among the individual variables, only the amount of ongoing training provided to employees had a significant $(\mathrm{p}$ $<.05)$ positive association with the adoption of nonunion arbitration. However, the group of four HPWS variables did produce a significant $(p<.01)$ improvement when added to the prediction equation for peer review procedures in the second model. Among the individual variables, use of self-directed teams had a significant $(\mathrm{p}<.05)$ positive association with the adoption of peer review procedures. Surprisingly, the extent of electronic monitoringwhich I characterized as a non-HPWS strategy-also had a positive, although only marginally significant $(\mathrm{p}<.10)$, association with the adoption of peer review procedures.

Litigation threat. Hypothesis 2 proposed that stronger litigation threats to the organization would be associated with the adoption of nonunion arbitration procedures. Addition of the set of two litigation threat variables produced a significant improvement in the first model $(\mathrm{p}<.01)$. Establishments in states that had adopted the implied contract exception to the doctrine of employment-at-will were more likely than other establishments to have nonunion arbitration procedures $(\mathrm{p}<.05)$. Establishments with a higher proportion of female employees were also more likely to have nonunion arbitration procedures $(\mathrm{p}<.05)$. This support for a relationship between litigation threats and the adoption of nonunion arbitration is in contrast to the results for peer review procedures. Adding the variables representing the strength of the litigation threat to the prediction equation for peer review procedures produced no statistically significant improvement in the model. Furthermore, neither of the 
individual litigation threat variables has a statistically significant association with the adoption of peer review procedures.

Unionization threat. Hypothesis 3 proposed that stronger unionization threats would be associated with the adoption of peer review procedures. Addition of the set of two unionization threat variables produced a significant $(\mathrm{p}<.01)$ improvement in the second model. Both individual variables also have statistically significant associations with peer review procedures in the predicted directions: location of the establishment in a right-to-work state had a significant $(\mathrm{p}<.05)$ negative association with adoption of peer review procedures, and greater emphasis on union substitution in handling disputes had a significant $(\mathrm{p}<$ $.05)$ positive association. These results contrast with those obtained when the unionization threat group of variables is inserted into the prediction equation for nonunion arbitration in the fourth model reported in Table 2. Addition of the unionization threat variables did not produce a statistically significant improvement in the model, and neither of the individual variables had a statistically significant association with the adoption of nonunion arbitration.

Establishment and work force characteristics. As expected, employee pay levels had a significant $(p<.05)$ positive association with the adoption of nonunion arbitration. Higher proportions of long tenure employees also had a significant $(\mathrm{p}<.05)$ positive association with the adoption of nonunion arbitration procedures. Both of these relationships are consistent with the argument that nonunion arbitration procedures are more likely to be adopted where the threat of litigation is greater. Both higher pay and longer tenure are factors that are likely to produce higher damage awards for an employee in successful litigation, and longserving employees may be particularly vulnerable to unfair dismissal by employers (Schwab 1993). However, although consistent with the litigation avoidance account, as noted above, these results could be due to alternative possible explanations, such as higher pay being associated with HPWSs or even the use of high wages as part of union substitution strategies.

Two of the variables had statistically significant associations with the adoption of peer review procedures: the proportion of short tenure employees had a significant ( $p$ $<.10)$ negative association, and the local unemployment rate a significant $(\mathrm{p}<.01)$ positive association. A possible explanation for the latter relationship may lie in the establishment location decisions of management. Kochan, Katz, and McKersie (1994) argued that in recent decades companies have increasingly avoided unionization and reduced labor costs by locating new facilities in areas of the country where existing industrial development, wages, and unionization are relatively low. In conjunction with these strategic locational decisions, they argue that many companies also adopted new sophisticated human resource practices designed to substitute for unionization and help maintain the nonunion status of these facilities (Kochan, Katz, and McKersie 1994). If companies in the telecommunications industry are adopting a similar strategy of locating new facilities in high unemployment areas to reduce labor costs and avoid unionization, this could explain the greater incidence of peer review procedures introduced as union substitution devices in these establishments.

Summary of the results. The results provide support for the importance of both litigation and unionization threats in the adoption of nonunion dispute resolution procedures. Yet the most striking aspect of the findings is the differentiation in the types of procedure adopted in response to different types of institutional pressure on organizations. The strength of litigation threats to the organization is associated with the adoption of nonunion arbitration, but not with the adoption of peer review procedures. Conversely, the strength of unionization threats to the organization is associated with the adoption of peer review, but not with the adoption of nonunion arbitration procedures. This difference in factors predicting adoption of procedures was present even though some establishments had both peer review and nonunion arbitration elements as part of 
Table 2. Predictors of Nonunion Procedures (logit).

\begin{tabular}{|c|c|c|c|c|}
\hline \multirow[b]{2}{*}{ Variable } & \multicolumn{2}{|c|}{ Nonunion Arbitration } & \multicolumn{2}{|c|}{ Peer Review } \\
\hline & $\begin{array}{l}\text { Coefficient } \\
\text { (s.e.) }\end{array}$ & $\begin{array}{l}\text { Change in } \\
\text {-2LogL for } \\
\text { Adding Group } \\
\text { of Variables }\end{array}$ & $\begin{array}{l}\text { Coefficient } \\
\text { (s.e.) }\end{array}$ & $\begin{array}{c}\text { Change in } \\
\text {-2LogL for } \\
\text { Adding Group } \\
\text { of Variables }\end{array}$ \\
\hline Size & $\begin{array}{c}-0.156^{*} \\
(0.084)\end{array}$ & & $\begin{array}{c}0.020 \\
(0.061)\end{array}$ & \\
\hline Exempt & $\begin{array}{l}-0.232 \\
(0.746)\end{array}$ & & $\begin{array}{l}-1.066 \\
(0.885)\end{array}$ & \\
\hline Education & $\begin{array}{l}-0.215 \\
(0.172)\end{array}$ & & $\begin{array}{c}0.258 \\
(0.182)\end{array}$ & \\
\hline Unemployment & $\begin{array}{c}0.120 \\
(0.152)\end{array}$ & & $\begin{array}{l}0.452 * * * \\
(0.161)\end{array}$ & \\
\hline Short Tenure & $\begin{array}{l}-0.642 \\
(1.021)\end{array}$ & & $\begin{array}{c}-2.399 * \\
(1.365)\end{array}$ & \\
\hline Long Tenure & $\begin{array}{l}1.291 * * \\
(0.609)\end{array}$ & & $\begin{array}{c}0.216 \\
(0.752)\end{array}$ & \\
\hline Pay $(\log )$ & $\begin{array}{l}2.023 * * * \\
(0.709)\end{array}$ & & $\begin{array}{c}0.533 \\
(0.761)\end{array}$ & \\
\hline$H P W s:$ & & 7.63 & & $16.86 * * *$ \\
\hline Teams & $\begin{array}{l}1.061 \\
(0.667)\end{array}$ & & $\begin{array}{l}2.051 * * * \\
(0.686)\end{array}$ & \\
\hline Training & $\begin{array}{l}0.301 * * \\
(0.131)\end{array}$ & & $\begin{array}{c}0.065 \\
(0.129)\end{array}$ & \\
\hline Temps & $\begin{array}{l}-0.324 \\
(1.792)\end{array}$ & & $\begin{array}{l}-4.795^{*} \\
(2.880)\end{array}$ & \\
\hline Electronic Monitoring & $\begin{array}{c}0.506 \\
(0.558)\end{array}$ & & $\begin{array}{c}1.354^{*} \\
(0.767)\end{array}$ & \\
\hline Litigation: & & $11.44 * * *$ & & 0.59 \\
\hline Implied Contract & $\begin{array}{l}1.076^{*} \\
(0.575)\end{array}$ & & $\begin{array}{c}0.174 \\
(0.526)\end{array}$ & \\
\hline Female & $\begin{array}{l}1.672^{* *} \\
(0.684)\end{array}$ & & $\begin{array}{c}-0.364 \\
(0.591)\end{array}$ & \\
\hline Unionization: & & 1.41 & & $10.27 * * *$ \\
\hline Union Substitution & $\begin{array}{c}0.099 \\
(0.096)\end{array}$ & & $\begin{array}{l}0.241 * * \\
(0.122)\end{array}$ & \\
\hline Right to Work & $\begin{array}{c}-0.320 \\
(0.494)\end{array}$ & & $\begin{array}{l}-1.374 * * \\
(0.548)\end{array}$ & \\
\hline Constant & $\begin{array}{c}-22.756^{* * * *} \\
(6.842)\end{array}$ & & $\begin{array}{r}-13.009^{*} \\
(7.503)\end{array}$ & \\
\hline $\begin{array}{l}-2 \log \mathrm{L} \\
\text { Pseudo R-sq. }\end{array}$ & $\begin{array}{r}144.80 * * \\
0.1756\end{array}$ & & $\begin{array}{r}123.01 * * \\
0.2551\end{array}$ & \\
\hline
\end{tabular}

$\mathrm{N}=165$.

*Statistically significant at the .10 level; **at the .05 level; ***at the .01 level.

multi-step procedures. In preliminary case study research, one of the more surprising findings was that in two of the cases both peer review and nonunion arbitration procedures were adopted within the same organizations, yet the two procedures were 
adopted at different points in time and in response to different institutional pressures, with peer review being adopted in response to unionization threats, nonunion arbitration in response to litigation pressures (Colvin 1999). The results from the survey data analysis provide strong support for the preliminary suggestion from the case studies that variation in the nature of institutional pressures on the organization drives variation in the types of dispute resolution procedures adopted in response to these pressures. At the same time, the results also provide support for an association between practices associated with high performance work systems and the adoption of peer review procedures, though not the adoption of nonunion arbitration.

\section{Discussion}

A central theme in the analysis presented here is that institutional forces continue to play a major role in shaping the nature of contemporary employment relations. Even in an era of declining levels of direct union representation, these institutional pressures are shaping the governance of nonunion workplaces. Yet the role of institutions in the picture presented here is a more ambiguous and contradictory one than the traditional industrial relations vision of institutions protecting employees against the destructive effect of unchecked market forces (Kaufman 1993). The present study has presented evidence supporting the importance of pressures from the institutional environment in the organizational adoption of dispute resolution procedures. However, in the processes described here organizations are adopting their own internal institutional structures that serve to exclude influences from the external institutional environment and thereby safeguard managerial power and control over the organization.

The two types of dispute resolution procedure examined here, nonunion arbitration and peer review procedures, represent especially strong procedures from a due process perspective, in that they both in- volve the use of non-managerial decisionmakers. As a consequence, it might be expected that adoption of these procedures would reflect strong organizational acceptance of justice norms leading to the enhancement of industrial citizenship in the workplace. Yet, the results suggest that adoption of both of these types of procedures is associated with strong institutional threats to the organization-in the case of nonunion arbitration, the threat of litigation, and in the case of peer review, the threat of unionization. Adding non-managerial decision-makers to dispute resolution procedures may enhance due process relative to procedures with managerial decision-makers, but it is a product of a process of limiting employee recourse to external institutions (to the courts in the case of nonunion arbitration, and to unions in the case of peer review). This produces a duality in the role of dispute resolution procedures: while providing a structure to enforce employee rights of citizenship within the organization, they also help to constitute the organization as a citadel protected against pressures from the external environment.

This analysis helps explain how institutional pressures can drive variation in organizational outcomes. One of the more striking results presented here, confirming an insight from the preliminary case study research, is the strong differentiation between the factors inspiring the adoption of different types of procedures. Adoption of nonunion arbitration was strongly associated with litigation threats but not associated with unionization threats, whereas adoption of peer review was strongly associated with unionization threats but not with litigation threats. Each type of procedure has a particular advantage as a response to the corresponding institutional threat. The courts' deferral to arbitration agreements following the Supreme Court's 1991 Gilmer decision enabled organizations to use nonunion arbitration procedures as an effective bar to employee access to the courts; and the ability of peer review to serve as a mechanism for employee involvement in dispute resolution in the workplace with- 
out violating the National Labor Relations Act makes it a particularly effective union substitution device for avoiding union organizing drives.

These influences of the nature of the institutional pressures on the structure of procedures help explain the variation in the types of procedure adopted. Nonunion arbitration procedures are likely to be adopted where litigation threats are particularly strong and peer review procedures where unionization threats are particularly strong. Variations across organizations in the adoption and structure of dispute resolution procedures correspond to variations in the strength of litigation and unionization threats.

Identification of unionization threats as an important institutional influence on the adoption of dispute resolution procedures is one respect in which this study differs from some previous work (Feuille and Delaney 1992; Delaney and Feuille 1993). Perhaps relevant in this regard is the fact that this study is based on a single industry, telecommunications, that has a relatively high level of unionization compared to the economy as a whole. Approximately onethird of employees in the industry are represented by unions, compared with only one-tenth of private sector employees in the economy as a whole (Katz 1997; Keefe and Batt 1997). Although research does suggest that the threat of unionization can strongly influence management behavior even when levels of unionization in an industry are relatively low (Taras 1997), it is clearly the case that in some industries unionization is virtually nonexistent and unlikely to be a strong influence. However, noting this difference between industries implies not that the threat of unionization is an unimportant factor influencing nonunion employment practices, but rather that the variation across industries in the threat of unionization may help explain cross-industry variation in employment practices. Indeed, it is arguable that the diversity in outcomes would be even greater if we were to extend the perspective from the private sector setting of the present study to include the public sector, in which many entirely different institutional dynamics come into play.

Although my primary focus has been on the role of institutional factors, the results of this study also provide support for a link between the use of self-directed work teams-one of the hallmarks of high performance work systems-and the adoption of peer review procedures. One possible reason for this link is that both self-directed work teams and peer review procedures represent structures for employee involvement in the workplace. As found in the preliminary case studies, to the degree that management transfers decision-making authority to employees to improve productivity and quality, it is likely to find increased employee expectations for involvement in other areas, such as workplace dispute resolution.

If we turn back to the initial question of what is driving the adoption of nonunion dispute resolution procedures, the answer apparently is complex. Support has been found for the influence of the rise in individual employment rights litigation and the new doctrines of court deferral to nonunion arbitration. Yet, evidence was also found supporting the continued importance of the older institutional factor of union organizing pressures and management union substitution practices. Finally, in contrast to these institutional explanations, support was also found for the influence of management human resource and work organization strategies. Perhaps even more perplexing, despite this identification of three different factors driving the adoption of nonunion dispute resolution procedures, the current adoption of nonunion procedures remains limited and there continues to be wide variation in the types of procedures adopted. The picture presented is one of a diversity of forces leading to variation in outcomes across workplaces, rather than a single key factor producing convergence on a common outcome. Although this picture will disappoint anyone hoping for the emergence of a single systemic answer, it is in keeping with the view that a major development in con- 
temporary industrial relations is the growth of variation in employment practices (Katz and Darbishire 2000), and it suggests how both institutions and human resource management strategies are helping to drive one aspect of this variation.

\section{REFERENCES}

Appelbaum, Eileen, Thomas Bailey, Peter Berg, and Arne L. Kalleberg. 2000. Manufacturing Advantage. Ithaca, N.Y.: ILR Press (an imprint of Cornell University Press).

Arthur, Jeffrey B. 1992. "The Link between Business Strategy and Industrial Relations Systems in American Steel Minimills." Industrial and Labor Relations Review, Vol. 45, No. 3 (April), pp. 488-506.

Berenbeim, Ronald. 1980. Nonunion Complaint Systems: A Corporate Appraisal. New York: The Conference Board.

Blau, Peter M., and Richard A. Schoenherr. 1971 The Structure of Organizations. New York: Basic Books.

Bronfenbrenner, Kate. 1997. "The Role of Union Strategies in NLRB Certification Elections." Industrial and Labor Relations Review, Vol. 50, No. 2 (January), pp. 195-212.

Bureau of National Affairs (BNA). 1999. Individual Employment Rights Manual. Washington, D.C.

Colvin, Alexander J.S. 1999. "Citizens and Citadels: Dispute Resolution and the Governance of Employment Relations." Ph.D. Diss., Cornell University.

Delaney, John T., and Peter Feuille. 1993. "The Determinants of Nonunion Grievance and Arbitration Procedures." Proceedings of the 44th Annual Meeting of the IRRA. Madison, Wis.: IRRA, pp. 52938 .

Delery, John E. 1998. "Issues of Fit in Strategic Human Resource Management: Implications for Research." Human Resource Management Review, Vol. 8, No. 3, pp. 289-309.

Delery, John E., and Harold D. Doty. 1996. "Modes of Theorizing in Strategic Human Resource Management: Tests of Universalistic, Contingency, and Configurational Performance Predictions." Academy of Management Journal, Vol. 39, No. 4 (December), pp. 802-35.

Dertouzos, James N., Elaine Holland, and Patricia Ebener. 1988. The Legal and Economic Consequences of Wrongful Termination. Santa Monica, Calif.: Rand Institute for Civil Justice.

Dertouzos, James N., and Lynn A. Karoly. 1991. Labor-Market Responses to Employer Liability. Santa Monica, Calif.: Rand Institute for Civil Justice.

Dunlop, John T., and Arnold M. Zack. 1997. Mediation and Arbitration of Employment Disputes. San Francisco: Jossey-Bass.

Edelman, Lauren B., Steven E. Abraham, and Howard S. Erlanger. 1992. "Professional Construction of Law: The Inflated Threat of Wrongful Discharge." Law and Society Review, Vol. 26, No. 1, pp. 47-83.

Edelman, Lauren B., Christopher Uggen, and Howard
S. Erlanger. 1999. "The Endogeneity of Legal Regulation: Grievance Procedures as Rational Myth." American Journal of Sociology, Vol. 105, No. 2 (September), pp. 406-54.

Edwards, Richard T. 1979. Contested Terrain. New York: Basic Books.

Epp, Charles R. 1990. "Connecting Litigation Levels and Legal Mobilization: Explaining Interstate Variation in Employment Civil Rights Litigation." Law and Society Review, Vol. 24, No. 1, pp. 145-63.

Ewing, David W. 1989. Justice on the Job: Resolving Grievances in the Nonunion Workplace. Boston: Harvard Business School Press.

Feuille, Peter, and Denise R. Chachere. 1995. "Looking Fair or Being Fair: Remedial Voice Procedures in Nonunion Workplaces." Journal of Management, Vol. 21, No. 1 (March), pp. 27-42.

Feuille, Peter, and John T. Delaney. 1992. "The Individual Pursuit of Organizational Justice: Grievance Procedures in Nonunion Workplaces." Research in Personnel and Human Resources Management, Vol. 10. Greenwich, Conn.: JAI Press, pp. 187-232.

Folger, Robert, and Russell Cropanzano. 1998. Organizational Justice and Human Resource Management. Thousand Oaks, Calif.: Sage.

Freeman, Richard B., and James L. Medoff. 1984. What Do Unions Do? New York: Basic Books.

General Accounting Office (GAO). 1995. Employment Discrimination: Most Private-Sector Employers Use Alternative Dispute Resolution. GAO/HEHS-95-150 Employment Discrimination. Washington, D.C.

Goddard, John, and John T. Delaney. 2000. "Reflections on the 'High Performance' Paradigm's Implications for Industrial Relations as a Field." Industrial and Labor Relations Review, Vol. 53, No. 3 (April), pp. 482-502.

Huber, Peter J. 1967. “The Behavior of Maximum Likelihood Estimates under Non-Standard Conditions." Proceedings of the Fifth Berkeley Symposium on Mathematical Statistics and Probability, Vol. 1, pp. 221-33.

Huselid, Mark A. 1995. "The Impact of Human Resource Management Practices on Turnover, Productivity, and Corporate Financial Performance." Academy of Management Journal, Vol. 38, No. 3 (June), pp. 635-72.

Ichniowski, Casey, Thomas A. Kochan, David Levine, Craig Olson, and George Strauss. 1996. "What Works at Work: Overview and Assessment." Industrial Relations, Vol. 35, No. 3 (Fall), pp. 356-74.

Ichniowski, Casey, Katherine Shaw, and Giovanna Prennushi. 1997. "The Effects of Human Resource Management Practices on Productivity: A Study of 
Steel Finishing Lines." American Economic Review, Vol. 87, No. 3 (June), pp. 291-313.

Katz, Harry C., ed. 1997. Telecommunications: Restructuring Work and Employment Relations Worldwide. Ithaca, N.Y.: ILR Press (an imprint of Cornell University Press).

Katz, Harry C., and Owen R. Darbishire. 2000. Converging Divergences: Worldwide Change in Employment Relations. Ithaca, N.Y.: ILR Press (an imprint of Cornell University Press).

Katz, Harry C., and Thomas A. Kochan. 2000. An Introduction to Collective Bargaining and Industrial Relations, 2nd edition. New York: Irwin McGraw Hill.

Kaufman, Bruce. 1993. The Origins and Evolution of the Field of Industrial Relations. Ithaca, N.Y.: ILR Press.

Keefe, Jeffrey H., and Rosemary Batt. 1997. "United States.” In Harry C. Katz, ed., Telecommunications: Restructuring Work and Employment Relations Worldwide. Ithaca, N.Y.: ILR Press (an imprint of Cornell University Press), pp. 31-88.

Klaas, Brian S., and Daniel C. Feldman. 1993. "The Evaluation of Disciplinary Appeals in Non-Union Organizations." Human Resource Management Review, Vol. 3, No. 1, pp. 49-81.

Kochan, Thomas A., Harry C. Katz, and Robert B. McKersie. 1994. The Transformation of American Industrial Relations. Ithaca, N.Y.: ILR Press.

Lewin, David. 1997. "Workplace Dispute Resolution." In David Lewin, Daniel J.B. Mitchell, and Mahmood A. Zaidi, eds., The Human Resource Management Handbook, Part II. Greenwich, Conn.: JAI Press, pp. 197-218.

MacDuffie, John-Paul. 1995. "Human Resource Bundles and Manufacturing Performance: Organizational Logic and Flexible Production Systems in the World Auto Industry." Industrial and Labor Relations Review, Vol. 48, No. 2 (January), pp. 197221.

McCabe, Douglas M. 1988. Corporate Nonunion Complaint Procedures and Systems. New York: Praeger.

Miles, Thomas J. 2000. "Common Law Exceptions to Employment at Will and U.S. Labor Markets." Journal of Law, Economics, and Organizations, Vol. 16, No. 1, pp. 74-101.

Olson-Buchanan, Julie B. 1996. "Voicing Discontent: What Happens to the Grievance Filer after the Grievance?" Journal of Applied Psychology, Vol. 81, No. 1 (February), pp. 52-63.
Osterman, Paul. 1994. "How Common Is Workplace Transformation and Who Adopts It?" Industrial and Labor Relations Review, Vol. 47, No. 2 (January ), pp. 173-88.

1995. "Work/Family Programs and the Employment Relationship." Administrative Science Quarterly, Vol. 40, No. 4, pp. 681-700.

. 2000. "Work Reorganization in an Era of Restructuring: Trends in Diffusion and Effects on Employee Welfare." Industrial and Labor Relations Review, Vol. 53, No. 2 (January), pp. 179-96.

Schwab, Stewart J. 1993. "Life-Cycle Justice: Accommodating Just Cause and Employment at Will." Michigan Law Review, Vol. 92, No. 1, pp. 8-62.

Shaw, Jason, John Delery, G. Douglas Jenkins, Jr., and Nina Gupta. 1998. "An Organization-Level Analysis of Voluntary and Involuntary Turnover." Academy of Management Journal, Vol. 39, No. 5 (December), pp. $1-15$.

Sheppard, Blair H., Roy J. Lewicki, and John W. Minton. 1992. Organizational Justice: The Search for Fairness in the Workplace. New York: Macmillan.

Slichter, Sumner, James J. Healy, and E. Robert Livernash. 1960. The Impact of Collective Bargaining on Management. Washington, D.C.: Brookings Institution.

Stone, Katherine V.W. 1996. "Mandatory Arbitration of Individual Employment Rights: The Yellow Dog Contract of the 1990s." Denver University Law Review, Vol. 73, pp. 1017-50.

1999. "Employment Arbitration under the Federal Arbitration Act." Chapter 2 in Adrienne E. Eaton and Jeffrey H. Keefe, eds., Employment Dispute Resolution and Worker Rights in the Changing Workplace. Champaign, Ill.: Industrial Relations Research Association.

Taras, Daphne G. 1997. "Managerial Intentions and Wage Determination in the Canadian Petroleum Industry." Industrial Relations, Vol. 36, No. 2 (Spring), pp. 178-205.

Westin, Alan F., and Alfred G. Felieu. 1988. Resolving Employment Disputes without Litigation. Washington, D.C.: Bureau of National Affairs.

Zack, Arnold M. 1999. "Agreements to Arbitrate and the Waiver of Rights under Employment Law." Chapter 3 in Adrienne E. Eaton and Jeffrey H. Keefe, eds., Employment Dispute Resolution and Worker Rights in the Changing Workplace. Champaign, Ill.: Industrial Relations Research Association. 